\title{
ADA BATU KEPALA KERBAU DI MASJID Studi terh adap Kepercayaan Masyarakat di Kabupaten Kampar
}

\author{
Suci Amalia \\ Jurusan Studi Agama-Agama, Fakultas Ushuluddin, UIN SUSKA Riau \\ Email: suci.amalia@uin-suska.ac.id \\ Hasbullah \\ Jurusan Studi Agama-Agama, Fakultas Ushuluddin, UIN SUSKA Riau \\ Email: hasbullah@,uin-suska.ac.id
}

\begin{abstract}
Abstrak
Masyarakat Desa Tanjung Berulak mempercayai adanya kepercayaan yang berkembang bahwa batu Kepala Kerbau memberikan banyak khasiat bagi orang yang meminum dan mandi air rendaman batu kepala kerbau tersebut. Tujuan Penelitian ini adalah, (1) Untuk mengetahui kepercayaan masyarakat terhadap Batu Kepala Kerbau di Masjid Djami' di Desa Tanjung Berulak kabupaten Kampar. (2) Untuk mengetahui Faktor-faktor yang mempengarubi kepercayaan masyarakat terbadap batu Kepala Kerbau di Masjid Djami' di Desa Tanjung Berulak Kabupaten Kampar. Jenis penelitian ini adalah metode penelitian kualitatif. Penelitian kualitatif ini merupakan penelitian yang dapat digunakan untuk meneliti kehidupan masyarakat, sejarah, tingkah laku, fungsionalisasi organisasi, gerakan sosial, dan hubungan krabatan. Teknik pengumpulan data yang digunakan metode observasi (pengamatan) dan wawancara (interview) dan dokumentasi. Teknik pengelolahan dan analisis data dilakukan dengan melalui tiga tahap, yaitu: reduksi data, penyajian data, dan penarikan kesimpulan. Hasil penelitian menunjukekan bahwa kepercayaan masyarakat terhadap batu kepala kerbau bahwa seseorang yang sakit dan bernazar meminum dan memandikan air rendaman batu kepala kerbau tersebut. Merek. mulai percaya pada saat batu kepala kerbau sering berpindah-pindah tempat dan menguek seperti suara kerbau. Adapun faktor-faktor yang memengarubi kepercayaan masyarakat terhadap batu kepala kerbau yaitu pertama dari faktor sejarah, kemudian dari faktor sosial budaya, dan dari faktor keyakinan.
\end{abstract}

Kata Kunci: Kepercayaan, Batu Kepala Kerbau, Masjid

\begin{abstract}
:
The people of Tanjung Berulak. Village believe that there is a growing belief that the Buffalo Head stone provides many benefits for people who drink and bathe in the water soaked by the buffalo head stones. The objectives of this study were, (1) To determine the community's trust in the Buffalo Head Stone in Masjid Djami 'in Tanjung Berulak Village, Kampar Regency. (2) This is to determine the factors that influence public trust in the Buffalo Head stone at the Djami 'Mosque in Tanjung Berulak Village, Kampar Regency. This type of research is a qualitative research method. This qualitative research is research that can be used to examine people's lives, history, behavior, organizational functionalization, social movements, and kinship relations. The data collection technique used was the method of observation (observation) and interviews (interview) and documentation. Data processing and analysis techniques are carried out in three stages, namely: data reduction, data presentation, and conclusion drawing. The results showed that the public's belief in the buffalo head stone is that someone who is sick and has a vow to drink and bathe the water soaked by the buffalo bead stone. They began to believe when the buffalo head stones moved around and yawned like a buffalo. The factors that influence people's belief in the buffalo head stone are bistorical factors, then socio-cultural factors, and belief factors.
\end{abstract}

Keywords: Trust, Buffalo Head Stone, Mosque

\section{PENDAHULUAN}

Manusia pada dasarnya selalu ingin memenuhi kebutuhannya baik kebutuhan jasmani, seperti sandang, pangan, dan juga mereka harus memenuhi kebutuhan rohani mereka yang bersifat abstrak. Seseorang akan berusaha semaksimal mungkin untuk memenuhi kebutuhannya dengan 
menggunakan berbagai cara dengan kemampuan akal mereka, namun setiap usaha seseorang belum tentu akan berhasil sepenuhnya sesuai dengan keinginan mereka, dan bahkan di dalam usahanya tersebut seseorang mengalami kegagalan. Karena hal tersebut terkadang seseorang menggunakan cara-cara yang bertindak secara yang bersifat mistik atau gaib. ${ }^{1}$

Kehidupan beragama pada dasarnya merupakan kepercayaan terhadap keyakinan adanya kekuatan gaib, luar biasa atau supranatural yang berpengaruh terhadap kehidupan individu dan masyarakat, bahkan terhadap segala gejala alam. Kepercayaan itu menimbulkan perilaku tertentu, seperti berdoa, memuja dan lainnya, serta menimbulkan sikap mental tertentu, seperti rasa takut, rasa optimis, pasrah dan lainnya dari individu dan masyarakat yang mempercayainya. Karenanya, keinginan, petunjuk, dan ketentuan kekuatan gaib harus dipatuhi kalau manusia dan masyarakat ingin kehidupan ini berjalan dengan baik dan selamat. Kepercayaan beragama yang bertolak dari kekuatan gaib ini tampak aneh, tidak alamiah dan tidak rasional dalam pandangan individu dan masyarakat modern yang terlalu dipengaruhi oleh pandangan bahwa sesuatu diyakini ada kalau konkret, rasional, alamiah atau terbukti secara emperik dan ilmiah. ${ }^{2}$

Keyakinan agama merupakan kepercayaan atas doktrin ketuhanan seperti percaya terhadap adanya Tuhan, malaikat, akhirat, syurga, neraka, takdir dan lain-lain. Tanpa keimanan memang tidak akan tampak keberagamaan. Keimanan yang abstrak tersebut perlu didukung oleh perilaku keagamaan yang bersifat praktis yaitu ibadah. Ibadah adalah cara melakukan penyembahan kepada Tuhan dengan segala rangkainnya. Ibadah itu dapat menjaga keimanan, memberikan garis pemisah antara manusia itu sendiri dengan jiwa yang mengajaknya pada kejahatan. Ibadah itu pula yang menimbulkan rasa cinta pada keluruhan, gemar mengerjakan akhlak yang mulia dan amal perbuatan yang baik dan suci. Sebagai orang yang beragama, maka sudah tentu nilai religiusitas harus

${ }^{1}$ Rahmawita, kepercayaan masyarakat terhadap Erabambang (Suatu Tinjauan Sosio-Antropologi) Di Desa Pecong Kecamatan Biringbulu Kabupaten Gowa (Skripsi S1 UIN Alauddin Makassar, 2011), hlm 1.

${ }^{2}$ Bustanuddin Agus, Agama Dalam Kebidupan Manusia; Pengantar Antropologi Manusia (Jakarta; PT Raja Grafindo Persada, 2006), hlm 1. benar-benar tampak dalam bentuk implementasi sikap, perbuatan, atau perilaku serta ucapan dalam kehidupan sehari-hari. Orang yang beragama, mengaku beriman dan bertaqwa kepada Tuhan seharusnya menunjukkan sikap-sikap yang mencerminkan ketaatan pada aturan dan ajaran Tuhan. ${ }^{3}$

Kehidupan manusia, kepercayaan dan ketauhidan senantiasa ada dalam dirinya, yakni percaya kepada Tuhan atau yang kepada dianggap bisa menguasai dirinya dalam firman Allah Swt. Dalam surah al-Ikhlas ayat 1-2 dan surah an-Nisa ayat 48 sebagai berikut :

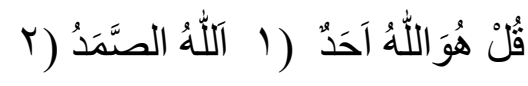

Katakanlah, "Dia-lah Allab Yang Maha Esa, Allah adalab Tuban yang bergantung kepada-nya segala sesuatu” (QS. al-Ikhlas/122: 1-2).

Surat di atas menjelaskan tentang zat, sifat dan perbuatan Allah yang Maha Esa. Surat di atas juga menjelaskan tentang kebutuhan makhluk kepada-Nya, yaitu hanya Allah Yang Maha Esa itu adalah harapan yang dituju oleh semua makhluk guna memenuhi segala kebutuhan, permintaan mereka, serta bergantung kepada segala sesuatu.

Surah an-Nisa ayat 48 :

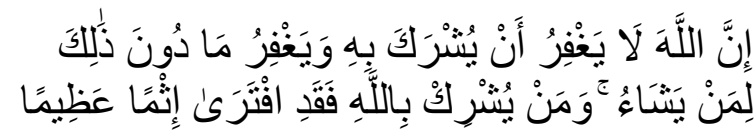

Sesungguhnya Allah tidak akan mengampuni dosa syirik, dan Dia mengampuni dosa selain dari (syirik) itu, bagi siapa yang dikehendaki$\mathrm{Nya}^{4}$

Kemusyrikan itu akan hanya membawa petaka, baik di dunia maupun di akhirat. Meski awalnya dijanjikan keindahan atau wujud kekayaan dunia. Namun, dalam kenyataan saat ini, pengalaman beragama di masyarakat masih diwarnai oleh kekuatan selain Allah. Karenanya

${ }^{3}$ Mardan Umar. "Urgensi Nilai-nilai Religius Dalam Kehidupan Masyarakat Heterogen Di Indoensia "Jurnal Civic Education”. 3, no. 1 (2019):75-76.

${ }^{4}$ Departemen Agama Republik Indonesia, Al-Qur'an dan Terjemahannya (Jakarta : PT Bumi Restu 1977), hlm.1118. 


\section{NUSANTARA; Journal for Southeast Asian Islamic Studies}

Vol. 16, No. 2, Desember 2020

berbagai kepercayaan dan ibadah agama telah menjadi sifat Universal manusia. Agama secara umum merupakan sebagai sistem kepercayaan dan praktik-praktik keagamaan yang berdasarkan beberapa nilai-nilai sakral, supranatural yang mengarahkan perilaku manusia, dan memberikan makna hidup, dan menyatukan pengikutnya ke dalam suatu komunitas moral. Setiap objek yang memiliki nilai sakral meskipun demikian tidak selalu identik dengan agama. Komponen sakral dari adat tradisi misalnya lebih menunjuk pada aspek "netral" atau "material" seperti dalam perbuatan keputusan tradisional, gotong-royong dan budaya material tradisional (masakan, taritarian, musik, lukisan, pakaian, arsitektur, dan lainlain). Setiap simbol mempunyai makna yang berbeda, bahkan mungkin bertentangan. Hal ini wajar dikarenakan makna suatu simbol lebih merupakan hasil interpretasi. ${ }^{5}$

Sebagai prinsip dan pegangan hidup, kepercayaan keagamaan diyakini sebagai kebenaran yang mutlak. Penganut agama, apalagi yang teramat kuat kepercayaan (keyakinan) terhadap suatu ajaran agama, biasa percaya pada agama sebagai ajaran sepenuhnya karena berasal dari Tuhan yang maha tahu. Penganut awam tidak bisa membedakan ajaran yang mutlak dan yang relatif dalam agama masing-masing yang mereka anut. Padahal yang pasti dalam ajaran agama adalah ajaran yang di ajarkan oleh wahyu yang benarbenar jelas dan tegas yang tidak mengandung penafsiran-penafsiran, yaitu ajaran-ajaran yang menyangkut tentang ajaran pokok dalam agama. Sedangkan pendapat, fatwa, dan penafsiran pemuka agama atau suatu aliran keagamaan bersifat relatif. ${ }^{6}$ Keyakinan agama didapatkan dari filsafat, budaya atau ajaran agama. Keyakinankeyakinan keagamaan diajarkan oleh keluarga dan masyarakat, dan didasarkan kepada ajaran yang diyakini terungkap dalam kitab suci atau berupa petunjuk dari kekuatan supranatural yang dipercayai. ${ }^{7}$

Sebagai sistem keyakinan, agama berbeda dari sistem-sistem keyakinan lainnya karena landasan keyakinan keagamaan adalah pada konsep suci dan ajaran-ajaran agama selalu bersumber pada wahyu

${ }^{5}$ Sindung Haryanto. Sosiologi Agama (Yogyakarta : ARRUZZ MEDIA, 2015), hlm. 28.

${ }^{6}$ Rahmawita, hlm 45.

${ }^{7}$ Ibid, hlm 3 . yang berisikan petunjuk-petunjuk Tuhan yang diturunkan pada Nabi. ${ }^{8}$ Agama merupakan seperangkat kepercayaan dan praktik-praktik bersangsi yang mendasari perkembangan moral komunitas. Agama sebagai suatu kreasi sosial "nyata" yang memperkuat solidaritas melalui kesamaan pandangan masyarakat mengenai moral. Agama merupakan dominan masyarakat (kolektif) seperti ritual yang dilakukan secara bersama-sama, sedangkan magis adalah praktik yang dilakukan secara individual. Dalam konteks masyarakat Indonesia, magis dapat disamakan dengan ritusritus yang dilakukan dukun atau paranormal dalam melayani permintaan (klien)-nya. Berkaitan dengan oposisi biner antara yang sakral dan yang profan, agama hadir sebagai jembatan yang menghubungkan antar keduanya. Hal itu diperlukan karena manusia membutuhkan kepastian di tengah ketidak pastian akan masa depannya. ${ }^{9}$

Kombinasi definisi substantif tentang agama pembedaan antara sakral dan profan dengan pandangan fungsionalis mengenai efek sosial dari integrasi sosial. Konsepsi agama meliputi pembedaan dua kategori yang saling berlawanan (oposisi biner), yakni antara yang sakral dan yang profan dan pembedaan antara kolektif dan individual. Konsepsi mengenai sakral (sacred) menunjuk pada sesuatu yang bersifat suci, ketuhanan, dan berada di luar jangkauan alam pikiran manusia. Sementara profan merupakan dunia nyata, dunia kehidupan sehari-hari yang berada di bawah kendali manusia. Dalam sosiologi, secara garis besar terdapat perbedaan pandangan mengenai agama. Perbedaan pandangan tersebut dapat dikategorikan ke dalam tiga persepektif, yaitu perspektif fungsional, konflik dan interaksionisme simbolis. Perspektif fungsional menekankan pada fungsi integratif agama bagi keseluruhan masyarakat. ${ }^{10}$

Agama dan kitab suci diyakini berasal dari Tuhan tetapi penafsiran dan pelaksanaanya berlangsung dalam kehidupan masyarakat. Agama meliputi seluruh aspek kehidupan manusia, sedangkan pertumbuhan masyarakat mempengaruhi pemikiran terhadap agama.

8Ibid, hal 4.

${ }^{9}$ Sindung Haryanto. Sosiologi Agama, hlm. 23.

${ }^{10} \mathrm{Ibid}$. hlm. 24-26. 
Hubungan antara alam dan manusia adalah keharusan yang tidak dapat ditolak, kerena hubungan tersebut memiliki nilai-nilai sakral yang sangat tinggi. Hal ini diungkapkan dalam personifikasi mistik kekuatan alam, yakni kepercayaan pada makhluk gaib, kepercayaan pada dewa pencipta, atau dengan mengkonseptualisasikan hubungan anatara berbagai kelomok sosial sebagai hubungan anatara binatang-binatang, burung-burung, atau kekuatan-kekuatan alam. ${ }^{11}$

Sampai saat ini masih banyak orang-orang yang memiliki kepercayaan tertentu terhadap benda-benda mati seperti, pohon beringin besar, batu, keris, peningalan nenek moyang, tempat pemakaman dan yang lain sebagainya. Begitu juga dengan masyarakat yang ada di Desa Tanjung Berulak Kabupaten Kampar, terdapat sebuah batu sondi berbentuk Kepala Kerbau di Masjid Djami' yang masih mempercayai Batu Kepala Kerbau memiliki khasiat akan tetapi, meskipun pola hidup modern telah mulai menambah kawasan ini masyarakat masih tetap percaya dengan adanya mistis di dalam batu berbentuk Kepala Kerbau sampai sekarang.

Masjid Djami' di pekarangannya terdapat sebuah kolam yang di dalamnya berisi air rendaman batu Kepala Kerbau yang bisa memberikan kesembuhan bermacam penyakit, setelah mereka dimandikan atas izin Allah SWT sehat kembali. Batu berbentuk Kepala Kerbau tersebut bisa berpindah arah dengan sendirinya. Mustahil dipindahkan orang karena batu sondi berbentuk Kepala Kerbau tersebut beratnya puluhan kilo. Masyarakat mempunyai kepercayaan dan keyakinan bahwa sebuah batu Kepala Kerbau yang ada di Masjid ini memilih kekuatan gaib. Bila air rendaman batu itu diminum dan dimandikan kepada seseorang yang menderita sakit, maka air tersebut diyakini dapat menyembuhkan. ${ }^{12}$

$\begin{array}{ccr}\text { Masyarakat Desa } & \text { Tanjung Berulak } \\ \text { mempercayai adanya kepercayaan yang }\end{array}$ berkembang bahwa batu Kepala Kerbau memberikan banyak khasiat bagi orang yang meminum dan mandi air rendaman batu kepala kerbau tersebut. Saat ini bukan hanya masyarakat Desa Tanjung Berulak saja yang datang ke Masjid Djami' untuk mengambil air rendaman batu

\footnotetext{
${ }^{11}$ Inda Sari. Ritual Sema Nagari Di Desa Tanjung Beringin Kecamatan Kampar Kiri Hulu(Skripsi S1 UIN Alauddin Makassar, 2011), hlm 3-4.
}

Kepala Kerbau, namun juga banyak masyarakat dari daerah lain yang datang mengunjungi tempat tersebut. Masyarakat yang datang dari daerah lain seperti, Malaysia, Singapura. Masyarakat tersebut datang dan mengambil air rendaman batu Kepala Kerbau karena mereka percaya khasiat terhadap batu Kepala Kerbau tersebut. Masyarakat yang datang ke Masjid Djami' memiliki pandangan yang berbeda tentang keberadaan batu Kepala Kerbau, sehingga mendorong peneliti untuk melakukan pencarian informasi mengapa batu Kepala Kerbau di Desa Tanjung Berulak masih dipercaya sampai sekarang.

Masyarakat yang mengunjungi batu Kepala Kerbau sangat beragam baik dilihat dari segi usia, jenis kelamin, pekerjaan maupun pendidikan. Masyarakat yang beragam tersebut mempunyai pola pikir yang tidak sama sehingga menimbulkan pandangan yang berbeda-beda terhadap batu Kepala Kerbau. Hal ini yang mendorong peneliti untuk mencari tahu bagaimana kepercayaan masyarakat terhadap batu Kepala Kerbau di Desa Tanjung Berulak. Setelah mengetahui pandanganpandangan masyarakat terhadap batu Kepala Kerbau tersebut, maka peneliti juga ingin mengetahui secara lebih mendalam apakah faktorfaktor yang mempengaruhi masyarakat terhadap batu Kepala Kerbau di lingkungan Masjid Djami' bagi masyarakat sekitarnya.

\section{Batu Kepala Kerbau Desa Tanjung Berulak}

Sesuai hasil penelitian diperoleh kesimpulan bahwa kisah terbentuknya batu Kepala Kerbau memang tidak bisa dipisahkan dari sejarah pembangunan Masjid Djami'. Masjid Djami' dibangun pada tahun 1901 secara bergotong royong masyarakat atau tukang dari 20 banjau kenegerian Air Tiris. Masyarakat bergotong royong mencari batu besar untuk menyangkal alas tiang Masjid, dari sungai Tanjung Berulak sampai ke sungai Pulau Lawas. Batu untuk sondi yang berbentuk Kepala Kerbau di temukan di Pulau Godang Bangkinang.

Setelah mendapatkan 40 batu besar, di bawa ke Masjid Djami'. Semua batu bisa dipasang dengan aman tanpa ada kendala, akan tetapi ada

${ }^{12 Z u l f a . ~ " P e n g a r u h ~ K e b u d a y a a n ~ I s l a m ~ P a d a ~ B a n g u n a n ~}$ Masjid Djami’ Air Tiris Kampar. "Jurnal Ilmu Budaya”. 3, no. 1 (2006):63. 
satu batu yang berbentuk batu Kepala Kerbau tidak bisa di pasang, sehingga datuk Mudo Songkal sebagai ketua pembangunan Masjid Djami' berkata suatu saat nanti batu ini akan berkhasiat.

Batu Kepala Kerbau ini sering berpindah tempat di sekitar bawah Masjid dan bahkan masuk dalam sumur sedalam 7 meter tanpa diketahui siapa yang memasukkan dan mengeluarkan. Sekarang batu kepala kerbau ini direndam dalam kulah masjid dan sejak direndam dia tidak menguek lagi dan air yang berisi batu Kepala Kerbau tersebut digunakan sebagai obat untuk masyarakat yang sakit sehingga air batu Kepala Kerbau dipercaya berkhasiat sebagai obat sampai sekarang. Hal ini menyebabkan banyaknya masyarakat yang semakin percaya dan berkunjung ke batu Kepala Kerbau di Masjid Djami' bahkan masyarakat luar daerah yang mengunjungi batu Kepala Kerbau.

Baik memandikan maupun diminum langsung air tersebut atau mengambil air rendaman batu Kepala Kerbau dimasukkan ke dalam botol untuk kebawa kerumah tanpa harus dimasak lebih dahulu. Jadi masyarakat percaya Batu Kepala Kerbau sampai sekarang karena masyarakat menganggap bahwa batu Kepala Kerbau tersebut merupakan lantaran dari Allah SW'T yang berguna bagi umat manusia.

\section{Faktor-faktor yang mempengaruhi kepercayaan masyarakat terhadap batu kepala kerbau di Masjid Djami' Desa Tanjung Berulak Kabupaten Kampar}

Masyarakat yang datang ke batu Kepala Kerbau di Masjid Djami' memiliki tujuan yang berbeda-beda sehingga menimbulkan presepsi yang berbeda. Kebudayaam orang-orang terdahulu yaitu mendatangi batu Kepala Kerbau di Masjid Djami' hingga sekarang masih terus dilestarikan pengujung dan masyarakat sekitar. Sangat mempercayai adanya batu Kepala Kerbau di Masjid Djami' Desa Tanjug Berulak. Hal tersebut sesuai dengan salah satu pengertian persepsi. Persepsi dapat didefenisikan sebagai proses menerima, menyeleksi, mengorganisasikan,

13 Ugi Nugraha. "Hubungan Persepsi, Sikap Dan Motivasi Belakjar Terhadap Hasil Belajar Pada Mahasiswa Pendidikan Olahraga Dan Kesehatan". "Jurnal Cerdas Sifa". Edisi 1 no. 1. Maret-Juni 2015 : 26-35. hlm 4. mengartikan, menguji, dan memberikan reaksi kepada rangsangan panca indra atau data. ${ }^{13} \mathrm{Jadi}$ persepsi masyarakat terhadap batu Kepala Kerbau banyak yang mempengaruhi, yaitu prasangka apa saja yang mempengaruhi persepsi mereka baik pengaruh asal-muasal adanya batu kepala kerbau, kebudayaan masyarakat, ataupun keyakinan individual.

Pertama, Faktor sejarah. Sesuai hasil penelitian di peroleh kesimpulan bahwa masyarakat yang mempercayai batu Kepala Kerbau memiliki pendapat atau presepsi yang hampir sama terhadap batu Kepala Kerbau salah satu alasan mereka mempercayai batu Kepala Kerbau tidaklah lepas dari peninggalan saat pembangunan Masjid Djami'. Karena batu Kepala Kerbau banyak memiliki keanehan kemudian datuk Ongku Mudo Songkal selaku ketua pembanguan Masjid Djami' berkata, suatu saat nanti batu Kepala Kerbau akan ber khasiat. Sehingga batu kepala kerbau dipercayai oleh masyarakat memiliki khasiat sampai sekarang. Hal ini akan dibahas tentang beberapa teori persepsi.

Faktor-faktor yang mempengaruhi persepsi yaitu Perhatian, Kesiapan mental, kebutuhan, sistem nilai, tipe kepribadian. ${ }^{14}$ Dari beberapa faktor tersebut faktor sejarah termasuk dalam perhatian, karena sejarah telah memperlihatkan bahwa batu kepala kerbau merupakan peninggalan pembangunan Masjid Djami'. Hal tersebut akan menjadi perhatian masyarakat dan akhirnya memiliki persepsi bahwa batu Kepala Kerbau merupakan peninggalan pembangunan Masjid Djami' yang di anggap menguatkan kepercayaan mereka terhadap batu Kepala Kerbau

Ciri-ciri persepsi antara lain rangsanganrangsangan yang diterima harus sesuai dengan moralitas, dunia persepsi mempunyai dimensi ruang seprti menyatakan atas-bawah, tinggirendah, luas-sempit, depan-belakang, dimensi persepsi juga mempunyai demensi waktu seperti cepat-lambat, tua-muda, objek-objek atau gejalagejala dalam dunia menyatu pengamatan mempunyai struktur yang menyatu dengan

14 Rohmaul Listyana dan Yudi Hartono. "Persepsi Dan Sikap Masyarakat Terhadap Penanggalan Jawa Dalam Penentuan Waktu Pernikahan (Studi Kasus Desa Jonggarang Kecamatan Barat Kabupaten Magetan Tahun 2013). "Jurnal Agastya ". 5, no. 1 (2015): 122. 
konteksnya. ${ }^{15}$ Persepsi masyarakat dilihat dari segi sejarah. Persepsi masyarakat tidak hanya diterima oleh indra mata saja, tetapi juga berada dalam dimensi ruang yaitu masyarakat Tanjung Berulak dan sekitarnya, dalam dimensi waktu yaitu disaat tertentu, dan kepercayaan masyarakat terhadap batu Kepala Kerbau dizaman dahulu sehingga menguatkan kepercayaan masyarakat.

Persepsi sendiri dipengaruhi oleh beberapa faktor yaitu perhatian, faktor fungsional dan faktor struktural. ${ }^{16}$ Kaitannya faktor tersebut dengan kepercayaan masyarakat terhadap batu Kepala Kerbau antara lain perhatian yaitu proses mental ketika rangkaian stimulus tentang sejarah asalusulnya batu Kepala Kerbau, faktor fungsional yaitu berasal dari peninggalan pembangunan Masjid Djami' dan batu Kepala Kerbau banyak memiliki keanehan, datuk Ongku Mudo Songkal berkata suatu saat batu Kepala Kerbau akan memberikan khasiat yang kemudian dipercaya khasiat sampai sekarang, faktor struktural yaitu bagaimana fakta batu Kepala Kerbau peninggalan saat pembangunan Masjid Djami' mempengaruhi hasil persepsi masyarakat tersebut.

Salah satu faktor yang mempengaruhi persepsi masyarakat adalah sesuatu yang menjadi perhatian, begitu pula persepsi masyarakakat terhadap Kepala Kerbau menjadikan peristiwa sejarah sebagai perhatian. Sejarah yang memperlihatkan bahwa batu Kepala Kerbau merupakan peninggalan saat pembangunan Masjid Djami', sehingga mempengaruhi persepsi masyarakat atas keberadaan batu Kepala Kerbau yang dipercaya mempunyai khasiat.

Kedua, Faktor sosial budaya. Sesuai hasil penelitian diperoleh kesimpulan bahwa masyarakat yang percaya terhadap batu Kepala Kerbau merupakan warisan leluhur mereka, kemudian dipercaya orang dari tahun ke tahun sehingga berusaha tetap menjaga kelestarian batu Kepala Kerbau.

Persepsi adalah kecendrungan seseorang terhadap sesuatu dalam ranah relatif, airtinya yaitu,

${ }^{15}$ Ika Mutia dan Elfida Agus. "Persepsi Mahasiswa Arsitektur Tingkat Satu Terhadap Prospek dan Masa Depan Profesi Arsitek. “Jurnal Rekayasa”. 8, no. 1 (2018): 89.

${ }^{16}$ Hadi Suprapto Arifin. "Analisis Faktor Yang Mempengaruhi Persepsi Mahasiswa Untirta Terhadap Keberadaan Perda Syariah Di Kota Serang. " Jurnal Penelitian Komunikasi dan Opini Publik. ”. 21, no. 1 (2017):91. persepsi individu terhadap sesuatu akan berbedabeda berdasarkan persepsi dari masing-masing orang Sehingga persepsi juga akan mempengaruhi perbedaan hasil belajar setiap individu. Persepsi adalah proses kombinasi dari sensasi yang diterima oleh organ atau hasil interpresentasinya (hasil olah otak) ${ }^{17}$ Hal ini sesuai dengan skema proses persepsi dalam persepsi stimulus datang dari luar, namun demikian sebagian besar stimulus datang dari luar diri individu yang bersangkutan.

Meskipun persepsi dapat melalui macammacam alat alat indera yang ada dalam diri individu, tetapi sebagian besar persepsi datang melalui alat indera penglihatan. Kebanyakan inividu hanya melihat dan lansung mempersepsi tanpa memikirkan lebih lanjut apa yang dipersepsikan benar. Begitu pula persepsi masyarakat terhadap batu Kepala Kerbau yang tidak hanya dipengaruhi oleh stimulus dari dalam seperti faktor pemikiran, dan juga faktor dari luar seperti tradisi dari suatu masyarakat yang akhirnya mempengaruhi persepsi seseorang untuk ikut mempercayai. Kebudayaan masyarakat yang sudah bertahun-tahun lamanya yang membuat masyarakat langsung mempercayai tanpa memikir-kan lebih lanjut apa yang di persepsikannya salah atau benar adanya.

Persepsi masyarakat terhadap batu Kepala Kerbau juga dipengaruhi oleh kebudayaan masyarakat Tanjung Berulak dan sekitarnya yang mempercayai khasiat batu Kepala Kerbau tersebut, hal ini sesuai dengan salah satu faktor persepsi yang diungkapkan oleh Rahmat yaitu faktor struktural. Faktor struktural yang berasal dari sifat stimuli fisik dan efek-efek saraf yang ditimbulkannya pada sistem saraf individu. ${ }^{18}$

Faktor struktural merupakan faktor yang berasal dari stimulus yang berasal dari lingkaran luar dari individu sendiri dan bagaimana sistem saraf bereaksi terhadap stimulus tersebut. Faktor ini yang mempengaruhi terbentuknya persepsi dengan menyatukan keseluruhan fakta-fakta yang

${ }^{17}$ Ugi Nugraha, hlm 4.

18 Hadi Suprapto Arifin. "Analisis Faktor Yang Mempengaruhi Persepsi Mahasiswa Untirta Terhadap Keberadaan Perda Syariah Di Kota Serang. " Jurnal Penelitian Komunikasi dan Opini Publik ”. 21, no. 1 (2017):91. 


\section{NUSANTARA; Journal for Southeast Asian Islamic Studies}

Vol. 16, No. 2, Desember 2020

ada. Baik yang berupa lingkungan objek tersebut sebagai tempat tinggal objek.

Faktor tersebut tidak akan dapat terpisahkan dari fakta yang satu dengan yang lain. Jadi faktor struktural ini lebih menekankan pada bagaimana stimulus berasal dari luar yang mempengaruhi sistem syaraf individu. Persepsi masyarakat terhadap batu Kepala Kerbau yang tidak hanya dipengaruhi oleh stimulus dari dalam seperti faktor pemikiran, tetapi juga faktor dari luar seperti faktor pemikiran, tetapi juga faktor dari luar seperti tradisi dari suatu masyarakat yang akhirnya mempengaruhi presepsi seorang untuk ikut mempercayai suatu kepercayaan tersebut. Masyarakat yang mempercayai bahwa batu Kepala Kerbau merupakan warisan leluhur mereka pada saat pembangunan Masjid Djami', mereka berusaha mempertahankan dan tetap mempercayai khasiat batu Kepala Kerbau sebagai obat dan sebagainya.

Ketiga, Faktor Keyakinan. Sesuai hasil penelitian diperoleh kesimpulan bahwa masyarakat yang mempercayai batu Kepala Kerbau berpendapat mereka tidak hanya mempercayai khasiat batu Kepala Kerbau tetapi mempercayai kekuasaan allah SWT yang terdapat pada batu Kepala Kerbau dan bagi mereka hal tersebut tidaklah musrik, dan keyakinan dalam diri setiap individu merupakan faktor penting yang sangat mempengaruhi presepsi masyarakat terhadap pada sautu hal. Persepsi individu dipengaruhi oleh dua faktor, yaitu faktor struktural dan faktor personal. ${ }^{19}$

Dalam faktor personal juga terdapat beberapa faktor yang mempengaruhi kecermatan persepsi. Faktor pertama adalah pengalaman, pengalaman ini bermakna jika semakin seorang mempunyai pengalaman maka akan semakin cermat dalam mempersepsi orang lain, jadi semakin banyak pengalaman masyarakat Tanjung Berulak dan sekitarnya semakin cermat pula dalam mempersepsi kepercayaan terhadap batu Kepala Kerbau.

Faktor kedua adalah motivasi, maka dari motivasi ini adalah jika seorang mempunyai motivasi terhadap orang lain maka presepsinya

${ }^{19}$ Afif Andi Wibowo, Persepsi Masyarakat Terhadap Mitos Ait Tiga Rasa di Lingkungan Makam Sunan Muria Kabupaten cenderung biasa dan tidak objektif, jadi persepsi masyarakat yang hanya didasarkan suatu tradisi masyarakat zaman dahulu yang mempercayai khasiat air batu Kepala Kerbau saja biasa prersepsinya cenderung tidak objektif. Faktor ketiga adalah intelegensi seorang akan memperngaruhi kecermatan dalam mempersepsi orang lain artinya semakin cerdas seseorang persepsinya akan semakin cerdas seseorang persepsinya akan semakin objektif dibandingkan orang yang intelegensinya rendah. Jadi faktor intelegensi seseorang sangat mempengaruhi persepsinya terhadap kepercayaan batu Kepala Kerbau dalam hal ini tentang keyakinan seseorang terhadap khasiat itu berasal dari Allah SWT. Semakin tinggi intelegensinya, maka akan membuat persepsinya semakin objektif. Keyakinan individu terhadap batu kepala kerbau merupakan salah satu faktor personal yang mempengaruhi persepsi masyarakat, dalam hal ini keyakinan masyarakat atas kebesaran Allah SWT atas adanya batu Kepala Kerbau. Masyarakat yang mempercayai batu Kepala Kerbau tetapi mempercayai kekuasaan Allah SWT yang terdapat pada batu Kepala Kerbau dan bagi mereka hal tersebut tidaklah musyrik.

Hubungan antara Agama Islam dengan tradisi Tolak Bala Atib Ko Ambai bisa menimbulkan tiga kemungkinan besar, yaitu tidak bertentangan, harmonis, dan bertentangan.

Pertama, tidak bertentangan. Hubungan antara Islam dengan Tradisi Tolak Bala Atib Ko Ambai dikatakan tidak bertentangan karena selama ini masyarakat menerima pendidikan terhadap tradisi Tolak Bala Atib Ko Ambai itu dari lingkungan tempat ia tinggal. Kemudian Tradisi Tolak Bala Atib Ko Ambai dilaksanakan oleh masyarakat dipandu oleh Tuan guru dari Tarikat Naqsabandi dan di akui oleh majlis ulama setempat dan di dukung oleh pemerintah setempat. diiringi dengan doa-doa yang sering digunakan dalam ajaran Islam, dan Tradisi Tolak Bala Atib Ko Ambai sudah menjadi sebagian dari kehidupan masyarakat Kubu Babussalam yang belum pernah ditinggalkan, walaupun dikalangan masyarakat yang bertentangan dengan tradisi Tolak Bala. Sehingga

Kudus ( Skripsi Universitas Negeri Semarang, 2011), Hlm, 104. 
masyarakat menganggap Tradisi Tolak Bala tidak bertentangan dengan Agama Islam.

Kedua, Harmonis. Hubungan antara masyarakat Islam dengan Ritual Tradisi Tolak Bala Atib Ko Ambai menciptakan keharmonisan karna Masyarakat menganggap hubungan antara agama Islam dengan tradisi Tolak Bala Atib Ko Ambai selama ini tidak ada masalah, sebab masyarakat belum pernah menyaksikan terjadinya perdebatan atau konflik atas perselisihan pendapat terhadap tradisi Tolak Bala di Kalangan Masyarakat Kubu Babusslam. Oleh karna itu tradisi tolak bala Atib Ko Ambai tetap berlansung dan di lestarikan sampai sekarang.

Ketiga, Bertentangan. Tradisi Tolak Bala Atib Ko Ambai bertentangan dengan Aqidah Islam, apabila masyarakat mengkhawatirkan jika tradisi tolak bala tidak di laksanakan maka akan terjadi bencana dan wabah lain nya (berkeyakinan Ritual Tolak Bala tersebut yang menetukan segala sesuatu itu terjadi), maka masyarakat yang belum mampu mengenal antara Adat dan aqidah akan terjerumus kepada kemusrikan. Hal ini disebabkan seolaholah tradisi Tolak Bala Atib Ko ambai dapat membawa keuntungan, jika tidak mengikuti dan merayakan Tradisi Tolak Bala maka akan menimbulkan bencana. Dari anggapan tersebut justru mengundang kesesatan bagi umat manusia sehingga memudahkan umat manusia mempersekutukan Tuhan yang maha Esa.

Masyarakat Kubu Babussalam sampai saat ini masih melaksanakan tradisi Tolak Bala Atib Ko Ambai sebagaimana mestinya dilaksanakan pada masa lalu, memang saat ini arus perkembangan zaman sangat pesat dan masyarakat mengkhawatirkan tradisi Tolak Bala Atib Ko Ambai akan hilang dari kehidupannya. Anggapan masyarakat jika Tradisi Tolak Bala Atib Ko Ambai itu dihilangkan dari kehidupan maka sedikit orang yang merespon terhadap hal tersebut karena masyarakat sudah sibuk dengan hal-hal yang modernisasi dengan mudah memperoleh kenyataan. Masyarakat sudah sangat percaya tentang hal tabu yang terus menerus berkembang tentang efek yang timbul dikemudian hari jika tidak Tradi Tolak Bala Atib Ko Amabai tidak di lakukan setiap tahun nya.

\section{Kesimpulan}

Berdasarkan hasil penelitian dan pembahasan, maka dapat disimpulkan: Kepercayaaan masyarakat Desa Tanjung Berulak terhadap batu Kepala Kerbau, seseorang yang sakit dan bernazar meminum dan memandikan air rendaman batu Kepala Kerbau tersebut. Masyarakat Desa Tanjung Berulak percaya bahwa batu Kepala Kerbau itu sakral atau mempunyai kekuatan luar biasa. Mereka mulai percaya pada saat batu Kepala Kerbau sering berpindah-pindah tempat dan menguek seperti suara kerbau. Faktor-faktor yang mempengaruhi kepercayaan masyarakat terhadap batu Kepala Kerbau di Masjid Djami’ di Desa Tanjung Berulak Kabupaten Kampar. Kepercayaan masyarakat terhadap batu Kepala Kerbau dilihat dari beberapa faktor, yaitu adalah sebagai berikut:(a)kepercayaan masyarakat dilihat dari faktor sejarah yaitu sejarah yang memperlihatkan bahwa batu Kepala Kerbau merupakan peninggalan saat pembangunan Masjid Djami', karena batu Kepala Kerbau banyak memiliki keanehan datuk Ongku Mudo Songkal berkata suatu saat batu Kepala Kerbau akan berkhasiat, sehingga mempengaruhi persepsi masyarakat atas keberadaan batu Kepala Kerbau yang dipercaya mempunyai khasiat;(b)kepercayaan masyarakat dilihat dari faktor sosial budaya yaitu faktor dari luar seperti tradisi dari suatu masyarakat yang akhirnya mempengaruhi persepsi seorang untuk ikut mempercayai suatu kepercayaan tersebut;(c) kepercayaan masyarakat dilihat dari faktor keyakinan yaitu masyarakat yang memepercayai batu Kepala Kerbau berpendapat mereka tidak hanya mempercayai khasiat batu Kepala Kerbau itu, tetapi mempercayai kekuasaan Allah SWT yang terdapat pada batu Kepala Kerbau dan bagi mereka hal tersebut tidaklah musrik. 


\section{DAFTAR PUSTAKA}

Afif Andi Wibowo, Persepsi Masyarakat Terhadap Mitos Ait Tiga Rasa di Lingkungan Makam Sunan Muria Kabupaten Kudus. Skripsi Universitas Negeri Semarang, 2011.

Agus Bustanuddin, Agama Dalam Kebidupan Manusia ; Pengantar Antropologi Manusia Jakarta; PT Raja Grafindo Persada, 2006.

Depertemen Agama Republik Indonesia. AlQur'an dan terjemahannya, Jakarta : PT Bumi Restu, 1977.

Hadi Suprapto Arifin. "Analisis Faktor Yang Mempengaruhi Persepsi Mahasiswa Untirta Terhadap Keberadaan Perda Syariah Di Kota Serang. "Jurnal Penelitian Komunikasi dan Opini Publik ”. 21, no. 1, hlm 91. 2017.

Hardani dan Nur Hikmatul Auliya. "Metode Penelitian Kualitatif \& Kuantitatif" Yogyakarta: CV. Pustaka Ilmu. 2020.

Haryanto Sindung. Sosiologi Agama. (Yogyakarta : AR-RUZZ MEDIA), 2015.

Listyana Rohmaul dan Yudi Hartono. "Persepsi Dan Sikap Masyarakat Terhadap Penanggalan Jawa Dalam Penentuan Waktu Pernikahan (Studi Kasus Desa Jonggarang Kecamatan Barat Kabupaten Magetan Tahun 2013)“dalam Jurnal Agastya ”. 5, no. 1, 122, 2015.

Mardan Umar. "Urgensi Nilai-nilai Religius Dalam Kehidupan Masyarakat Heterogen Di Indoensia "Jurnal Civic Education". 3, no. 1, hlm 75-76. 2019.

Mutia Ika dan Elfida Agus. "Persepsi Mahasiswa Arsitektur Tingkat Satu Terhadap Prospek dan Masa Depan Profesi Arsitek. "dalam Jurnal Rekayasa ”. 8, no. 1, hlm 89. 2018.

Nugraha Ugi. "Hubungan Persepsi, Sikap Dan Motivasi Belakjar Terhadap Hasil Belajar Pada Mahasiswa Pendidikan Olahraga Dan Kesehatan" dalam Jurnal Cerdas Sifa". Edisi 1 No. 1, hlm 4 Maret-Juni 2015.
Nugrahani Farida. "Metode Penelitian Kualitatif Dalam Bidang Pendidikan Bahasa" Surakarta: Universitas Sebelas Maret Press, 2010.

Rahmawita, kepercayaan masyarakat terbadap Erebambang (Suatu Tinjauan SosioAntropologi) Di Desa Pecong Kecamatan Biringbulu Kabupaten Gowa. Skripsi S1 UIN Alauddin Makassar, 2011.

Salim dan Syahrum. "Metode Penelitian Kualitatif" Bandung : Ciptapustaka Media, 2012.

Sari Inda. Ritual Sema Nagari Di Desa Tanjung Beringin Kecamatan Kampar Kiri Hulu. Skripsi S1 UIN Alauddin Makassar, 2011.

Zulfa. "Pengaruh Kebudayaan Islam Pada Bangunan Masjid Djami' Air Tiris Kampar. "Jurnal Ilmu Budaya”. 3, no. 1, hlm 63. 2006. 